\title{
Os Livros do Coração: uma análise dos romances sentimentais do Século $X X$
}

\author{
Roberta Manuela Barros de Andradet, Erotilde Honório Silua?
}

Resumo: A literatura de massa é um objeto privilegiado para a análise dos valores sociais que circundam as sociedades contemporâneas. Entrementes, apesar de sua óbvia importância, poucos estudos têm se dedicádo à sua compreensão. Esse desprezo acadêmico é expresso pelo antagonismo entre gêneros literários considerados nobres e uma literatura popular menor, basicamente centrada na oralidade. Este artigo se propõe a fazer uma análise de discurso dos romances sentimentais da "Coleçáo da Biblioteca das Mogar"; publicados entre os anos de 40 e 60 do século XX, em especial, os romances assinados por $M$. Delly, comparando com seus herdeiros, a coleção "Romances do Coraçäo", identificada por suas séries, Jitila, Sabrina e Bianca, publicadas nos anos 80 do mesmo século. Apesar da "Colecão Romances do Coraçao" perdurar até hoje, escolhemos esta época especifica porque retrata o seu aparecimento no Brasil, quando se forma a sua sociedade leitora.

Palavras-chave: literatura de massa; romances sentimentais; análise de discurso.

Abstract: The mass literature is a privileged object for the analysis of the social values that surround the contemporaries societies. Meantime, although its obvious importance, fev studies have being dedicated to its understanding. This academic disdain is expressed for the antagonism between noble literary sorts and a popular simple literature, basically centered in the orality. This article proposes to make an analysis of speech of the sentimental romances of the "Collection of the I dilrary of the Young women", published between the years of 40 and 60 of century $X X$, in special, the romances written for M. Delly, comparing with its heirs, the collection "Romances of the Heart", called for its series, Sabrina, Jitia and Bianca, published in years 80 of the same century. Although the "Romances of the Hear" remains being published

\footnotetext{
1 Graduada cm Comunicação Social, mestre c doutora em Sociologia pela Universidade Federal do Cearã. Professora Adjunto $\mathrm{X}$ da Universidade Estadual do Ceari (Ul:Cl:). Professora Titular da Universidade de Fortaleza (Unifor).

2 Graduada em Comunicaçào Social, mestre c doutorn em Sociologia pela Universidade Federal do Ceará. (UFC). Professora $\lambda$ djunto IX da Universidade Federal do Cenrí. Professora Titular da Universidade de Fortaleza (Unifor).
} 
until today, choose this specific time because it portraies its appearance in Brazil, when its reading society is formed.

Keywords: mass literature; sentimental romances; speech analyses.

\section{A Literatura de massa no século XX: entram em cena os romances cor de rosa}

O campo literário constituído tem dado, ao longo dos séculos, particular ênfase ao que chamamos de "alta literatura", cujas regras de compreensão se alicerçam em padrões eruditos de classificação em detrimento de uma literatura que se gesta no interior da cultura de massa, geralmente classificada como subliteratura, literatura de entretenimento ou literatura popular. Essa classificação pejorativa se expressa claramente com o nascimento, a partir do século XIX, da produção de uma literatura popular, encontrada numa seção específica dos jornais, na qual se mesclavam elementos da cultura popular com o imaginário advindo dá recém-constituída cultura de massa. Era o chamado romance-folhetim. Da estrutura desse romance popular, incrustado na cultura de massa, ou pelo menos do que Meyer (1996) chamou de sua "terceira fase", nascem os atuais romances sentimentais, ou como chamados na nomenclatura francesa, os romances cor de rosa. Esses romances são, pois, o objeto de análise deste estudo ${ }^{4}$.

Os romances sentimentais, ao reunir na mesma estrutura narrativa elementos oriundos de matrizes culturais eruditas, massivas e populares, são um campo privilegiados para a compreensão dos sentidos sociais dos bens culturais presentes na contemporaneidade. Eleger como objeto de análise um produto da literatura de massa é, pois, como afirma Borelli (1997), extrapolar as concepções dicotômicas do campo literário. De um lado, apresenta-se a verdadeira literatura,

3 Os romances folhetins, em sua terceira fase, retratam o que Meyer (1996) chama de "dramas da vida" nos quais é mostrada a luta das personagens para a vivência do verdadeiro amor, usurpado por vilōes vis e pérfidos, que trazem os mais atrozes sofrimentos aos protagonistas.

4 Este trabalho faz parte de um projeto de pesquisa intitulado "Literatura de massa: uma análise dos romances de banca de revista" realizado $\mathrm{cm}$ uma parceria da Universidade Estadual do Ceará (UECE) com a Universidade de Fortaleza (Unifor), envolvendo professores e alunos dessas duas Instituições. Conta com a colaboração dos bolsistas Thiago Barreto, Fernanda Falcão e Raquel Holanda. 
com suas normas, hierarquias e modelos constituidos. Em oposição a ela, coloca-se um conjunto de escrituras que foge ao padrão reconhecido e como tal, é raramente reconhecido como objeto de estudo, classificado como não literário, subliterário ou contraliterário.

Desta forma, a rigidez analítica da crítica cultural exclui, naturalmente, do campo intelectual a produção cultural de massa, como é o caso dos romances sentimentais, o que acarreta uma notável escasse\% de pesquisas cientificas que se detenham nesse produto renegado pela comunidade literária. O desprezo acadèmico por essa vertente cultural, oriunda da dicotomia no interior do campo literário, nào é recente. Zumthor (1993) afirma existir um tradicional antagonismo entre gèneros literários considerados nobres, o texto escrito aceito e legitimado, pois, advindo da superioridade da cultura letrada oficial e uma literatura mais popular, de origem rural, basicamente centrada na oralidade.

Neste contexto, durante muitos anos, esses romances foram vistos, em especial pelos estudos feministas, como partícipes de uma estrutura de dominação masculina, mercadoria utilizada $\mathrm{cm}$ um sistema de troca e venda, portanto, sem autonomia textual. Esses romances regidos por modelos retóricos unjversais, conduziriam a uma posição de subordinação feminina em relação aos ditames autoritários das sociedades patriarcais, construindo uma opçào escapista e tendo como fim último a alienação e o conformismo social.

Porém, na década de 80 , outras visões começaram a se desenvolver na crítica especializada. Eco (1985), ao tecer considerações sobre O Nome da Rosa, best-seller de muito sucesso popular, em oposição ao que afirmara em outras ocasiões, defendia a idéia de que devemos pensar a literatura de massa como uma possibilidade de construção de um sentimento de profunda insatisfação com o aqui e o agora. Ao atingir a um vasto público, afirma $\mathrm{Eco}$, povoando seus sonhos, o romance popular deixa ao leitor a possibilidade de pensar uma realidade diferente da que vive. Este povoamento onírico pode não significar necessariamente uma fuga da realidade. Consolando este público, refugiando-o em um mundo de fantasia, pode, por sua vez, instigá-lo a pensar em mudanças e transformações na ordem vigente.

Radway (1987) na mesma direção constata que os romances cor de rosa são endereçados a mulheres que, ao contrário das que se adaptam às normas das sociedades patriarcais, expressam seu inconformismo com essas normas ao projetarem desejos e anseios 
que seus parceiros não conseguem suprir. De acordo com Radway, os romances cor de rosa imaginam paz e segurança nas relações amorosas justamente porque elas se constituem de dissensões, inseguranças e dificuldades. Os romances populares revelariam, assim, uma insatisfação com as formas como a relação homem e mulher se configuram na atualidade.

É nesse campo polêmico que se coloca nosso trabalho. A partir dele, algumas questões são levantadas, em especial, as que dizem respeito à forma como certo imaginário feminino produzido nesses romances tem se desenvolvido ao longo do século $\mathrm{XX}^{5}$. Para atingir tal pretensão, esse artigo se propõe a fazer uma análise de discurso, comparando os textos dos romances sentimentais da "Colegão da Biblioteca das Mocas", publicados" entre os anos de 40 e 60 do século $\mathrm{XX}$, pela Editora Nacional, em especial os romances assinados por M. Delly, com seus herdeiros, a coleção "Romances do Corafão", reconhecida por suas subdivisões denominadas de Sabrina, Júlia e Bianca, publicada nos anos 80 do mesmố século, pela Editora Harlequim. Apesar dos romances sentimentais Julia, Sabrina e Bianca perdurarem até hoje, inclusive com segmentaçốes em diversas subcoleções, optamos por esta época específica porque retrata o seu aparecimento, quando se forma a sua sociedade leitura no Brasil.

Selecionamos como répresente da "Coleção da Biblioteca das Mocas" os romances assinados por M. Delly devido a sua enorme popularidade no período em questão, sendo, inclusive, recomendados para a formação das moças de "familia" dessas décadas. M. Delly é o pseudônimo de dois irmãos gếmeos franceses, católicos fervorosos chamados Frederic Henri de la Rosiére (1870-1949) e Jeanne- Marie Henriette Petijean de La Rosiére (1875-1947). Esses dois irmãos, cremos, construíram um modelo exemplar da lógica da construção narrativa da literatura de massa daquele periodo.

Obviamente que ao lado de M. Delly havia outros autores de impacto como Elinor Glyn ${ }^{6}$ (considerada uma escritora "picante" para a época), Concordia Merrel e Bertha Ruck (consideradas as mais

\footnotetext{
5 Escolhemos realizar uma análise dos romances sentimentais produzidos no século $\mathrm{XX}$ porque cremos que o campo especializado tem negligenciado estas produçōes contemporâneas, ainda que elas tenham dito um espaço analítico bastante relevante quando se tratava de sua gênese no século XIX

6 Pseudônimo de Elinor Sutherland. Foi uma das precursoras da ficção erótica para mulheres. Foi ela quem cunhou o uso de It como um cufemismo para sexualidade ou para atração sexual.
} 
"modernas" dentre as autoras publicadas nesta coleção). No entanto, essas outras escritoras, apesar de muito populares, não alcançaram o sucesso que M. Delly conquistou no Brasil. Escolhemos M. Delly como exemplo para este trabalho porque esta publicação no Brasil tornou-se icone de una geração e sinônimo de romance sentimental neste periodo (Cunha, 1999). Apesar de fazermos referência aos livros de M. Delly neste trabalho, ressaltamos que a sua estrutura central foi seguida pela maior parte das autoras da "Colef̧ào Biblioteca das Moças".

No entanto, mais de vinte anos depois, o gènero romance sentimental ressurge por meio dos "Romances do Coraçào" encabeçados por coleções denominadas de Sabrina, Juilia e Bianca, grandes sucessos editoniais no Brasil e no estrangeiro, e até hoje no Brasil gozam de elevada popularidade. As primeiras coleções dos "Romances do Coraçāo" foram sucesso de vendas nesta década, com tiragens de seiscentos mil exemplares por mês, um recorde para a sociedade leitora brasileira. Sabrina, Júlia e Bianca sobrevivem até hoje com edições mensais nas bancas de revistas, fragmentadas em várias subcoleções". Mas, a popularidade da primeira linha editorial dos "Romances do Coraçào" foi tão surpreendente que, atualmente, são objeto de culto de um amplo público leitor que a eles têm acesso por meio da sua troca/venda nas bancas dos centros de cidades país afora.

Este estudo tem, pois, o objetivo de traçar um paralelo entre a estrutura e o argumento dos romances de $M$. Delly $y^{\gamma}$ e os seus similares nos anos 80, os romances sentimentais da coleção "Rommances do Coraçä". Cremos ser possivel compararmos estes dois conjuntos de obras, pois, apesar de pertencerem a gerações distintas, esses romances seguem uma estrutura básica muito semelhante. Temos, assim, o pressuposto de que nos produtos culturais de uma época encontram-se pistas para a compreensão das normas e valores vigentes nas sociedades que os configuram". Assim, entender, por meio de uma análise de discurso o que diferencia csses romances de acordo com cada época e o que permanece na estrutura mais profunda é o grande desafio deste trabalho.

7 A lidion Harlequim, em 2004, mudou of formato dos livers e a ipo de papel,

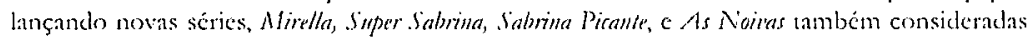
succsso de vendas.

8 Os romances de $\mathrm{M}$. Delly foram reditados em 1983 pela mesma editora Nacional, no cnanto, as rendas ficaram aquén do espendo, não sendo mas recditados posteriormente.

9 Lste inaginário scntimental pode ser percebido pela associaçiu secular contre muther/romance, como ben o definiu Cunha (2006). linurementes, ressaltamos que esta associaçào refere-se à mulher burguesa, "rainha dos cspaços privados", cercada por serviçais, que teria uma maior disponibilidade para a leitura de romances. 
Entendemos análise de discurso na mesma concepção de Bardin (1999) como um conjunto de técnicas de análise construído a partir de procedimentos sistemáticos de descrição do conteúdo das mensagens que permitem a inferência de conhecimentos relativos às condições de produção/recepção dessas mensagens. A nossa análise está centrada entre os seus suportes materiais -capas, títulos - e seus conteúdos -enredos, personagens e cenários (Cunha, 1999). A partir deste viés de análise, fizemos uma tipologia do herói e da heroína desses romances sentimentais nestes dois períodos, a forma como são retratados, os cenários nos quais estruturam suas ações, as indumentárias que carregam e as visões que possuem sobre casamento, amor, religião e sexo.

É interessante observar que apesar do tempo que nos separa de M. Delly e mesmo dos primeiros exemplares de Julia, Sabrina e Bianca, este gênero ainda sobrevive com bastante popularidade em quase todos os países ocidentais. Dai porque realizar uma reflexão sobre essas obras abre caminho para entendermos porque tais romances continuam a alimentar o imaginário de milhares de mulheres no mundo ocidental, apesar dos distanciamentos históricos, sociais, políticos e culturais que circunscrevem essas leitoras.

\section{Os romances de M. Delly: as puras e cândidas Cinderelas de outrora}

\subsection{Capas}

$\mathrm{Na}$ capa, um casal sorrindo, transmite uma idéia de felicidade. Em torno do casal, um cenário mágico de fantasia enfeitado de flores, árvores e pássaros. Esta representação imagética é típica dos romances sentimentais dos anos 40 e 60 do século passado. Neste clima de conto de fadas, nasce o amor, que se consolida pelos laços do matrimônio. Este é o imaginário que alimentava as leitoras da classe média brasileira neste período. Como nos lembra Cunha (2006), a associação entre romance e mulher é bem antiga e mais antiga é ainda a percepção de que o universo feminino está povoado por um contato íntimo entre a mulher e a natureza, entre espítito feminino, sonhos e devaneios.

Em M. Delly, esta relação é um tema recorrente e se baseia no velho estereótipo que associa o homem à cultura e a mulher à 
natureza e neste aspecto $M$. Delly não é original. Na história da literatura, há uma tendência clara a esta associação, uma vez que, na sociedade global, as mulheres sempre foram identificadas mais com a natureza do que com a cultura, talvez pelo maior envolvimento de seu corpo com a reprodução humana (Eisler, 1997). Desta forma, nesses romances, 'Quando a folbagem se monia, mma luz fugidia roçana-lbe or cabelor, aclarava-lhe o rosto atento.' (Foi o Destino, 1955:22). As cores usadas são claras, tênues, construindo um cenário nostálgico do século antetior. Para quebrar um pouco esta passividade, sào agregradas às capas dos romances de M. Delly, heroinas-crianças, de sorriso maroto, numa atjtude voluntariosa ou mimada, tipica da menina-rapazinho que ainda não se fez mulher. Os homens raramente aparecem nas capas. Tratase de uma narrativa feminina na qual a figura da mulher é central.

\subsection{Títulos}

Destinados ao público feminino, os títulos das obras reproduzem nomes de mulheres comuns à época Magali, Orieta, Eilfrita, Marizia, Mitsi, Eiza, Ondina, Luana, Nina Rosa" e faziam referència a substantivos como "alma", "cotaçào", "céu", "flor". Alguns exemplos de grandes sucessos daquele período foram: Meu Vestido Cor do Céth, Alma em Flor; Coraföer Inimigos, Enire Duas Almas, No Silêncio da Noite, A Casa dos Rouxinóis, Um Coragào entre Flores, A Cascata Rubra. Aqui, segue-se a tendència da literatura romántica do século XIX em associar sentimentos a expressões ou fases da natureza. Por outro lado, quando os títulos fugiam a esta orientação, apresentavam o cerne do conflito amoroso, tais como: Escrara... on Rainba?, Freimba, Foi o Destino, Noiva, Vendida, O Rei Kidji, O Fim de uma Valquiria, Vencido, A Vinganca de Ralph, Castelo em Rumar, A Solteirona, Diario de mma Aristocrata, O Homem sem Piedade, O Homem Desconbecido, O It, Terendo Sonbos. O Grande Momento, Cinzas do Pasrado, A Maltrapilla, Tudo se Paga.

\subsection{Personagens}

Neste contexto, as mulheres desses romances são puras e restritas ao lar. Sempre nobres senào em títulos (apesar de algumas 
os possuírem de fato), mas, em valores morais como honradez, inocência e castidade ${ }^{11}$. Ricas de nascença ou enriquecidas pelo casamento, têm uma vocação para a felicidade apesar de passarem por muitos infortúnios. Em geral, as heroínas de M. Delly são frágeis, cheias de sentimentalismos e de sofrimentos a serem expurgados.

Fisicamente, em geral, são brancas, seguindo um padrão europeu. Nas suas características físicas, expressavam-se seu caráter e dignidade. A alvura da pele já revela-lhe a retidão de caráter. Já a tonalidade dos cabelos podia variar entre as louras e as morenas. Se as escritoras são de origem francesa, há um predomínio de morenas (como é o caso de M. Delly), mas se possuem origem britânica (como é o caso de Elinor Glyn), há um predomínio de louras. Entrementes, louras ou morenas, quase todas possuem olhos claros.

O modelo feminino que predomina nesses romances é o da mulher de andar gracioso, passos curtos, rosto diáfano, tez rosada pronta para ruborizar a qualquer insinuação que fizesse referência ao sexo, à reprodução animal ou, até mesmo, a um galanteio mais ousado. Nada de decotes ou transparências, um busto que se pressentisse, um tornozelo que se mostrasse davam fortes motivos para reprimendas, sanções e auto punições. Em geral, os romances de M. Delly se detêm na descrição das mãos: macias, suaves, delicadas e finas, tais quais as mãos da Virgem Maria para quem oferecemos prendas nos ritos católicos. Os sorrisos são discretos, suaves, sonhadores a fim de não quebrar a harmonia com o todo. No vestir das moças, as roupas são flutuantes e etéreas. Não raro, os olhos de suas heroínas tinham 'a aveludada doçura de uma corola em for'.

Os homens são representados como fortes e viris, possuidores de grande inteligência e capacidade de decisão. São elegantes, protetores, corajosos, valentes, algumas vezes arrogantes e impetuosos, e autoritários. Não são caridosos como as heroínas, mas justos e bons. Reproduz-se aqui certo estereótipo que foi criado para o gênero, a mulher sempre ligada à emoção, ao altruísmo, à solidariedade; o homem associado à imparcialidade, ao espírito de competição

11 Em Elinor Glyn. as heroínas não são necessariamente castas. Como algumas de suas protagonistas são viúvas (nunca divorciadas), estas já possuem experiência sexual, embora tal fato nunca seja mencionado. Mas, mesmo viúvas, têm comportamentos sempre discretos. As referências às experiências sexuais anteriores simplesmente inexistem $\mathrm{cm}$ suas obras. Mas, tendo sido casadas ou não, as suas protagonistas estão sempre à procura de uma paixão arrebatadora. 
e a julgamentos racionais (Stoller, 1993).

$\Lambda$ s heroinas dos romances de $M$. Delly tinham sua scxualidadc abafada, reprimida sob o rigor de uma Igreja que abominava o pressentir de desejos sexuais, educando as mulhcres para sercm esposas fréis e mães devotadas (Dcl Priori, 2006). Em M. Delly, a religião aparece com uma força centrífuga. A ausència de crença em Deus ou de uma prática religiosa explícita era considerada um ato amoral. Em geral, as heroínas se sentiam desiludidas quando o eleito de scu coração não possuia suas ardentes convicções religiosas. As mulheres dos romances de $\mathrm{M}$. Delly são, assim, tementes a Deus, defensoras dos valores de un catolicismo fervoroso. Portanto, quando o seu amado não professava tais convicções, cabia à mulher conduzi-lo para o mundo da espiritualidade. 'Uma brusca desilusão lbe bania revelado com vaidosa fraqueza daquele espirito, a fragilidade de suas convições religiosas, de seus principios morais' (Foi o Destino, 1955: 78-79). Quando ela obtinha sucesso, submetia-se, tranqüilamente à orientação masculina. O homem se torna seu consclhciro e mentor $\mathrm{e} \mathrm{cm}$ roca se dobra à fé professada por suas mulheres.

Neste período, a sexualidade da mulher pautava-se pelas normas sociais referentes ao sexo feminino c pelo severo rigor religioso. De acordo com a Igreja, particularmente o catolicismo, religião predominante nos anos 40 e 60 , a mulher instigava os desejos $c$ as fraquezas masculinas, sendo considerada ameaçadora à ordem social (Del Priori, 2001) O corpo feminino cra tido como perigoso e por ele um homem podia perder sua honra. Somente as vilās, geralmente, estrangeiras, usavam roupas ousadas. Lembramos, aqui, que o imaginário que subescreve M. Delly ć o do medo de uma nova gucrera mundial, a ser deflagrada por uma poténcia estrangeira, como a alemã, por excmplo. Dai porque é a estrangcira, quase sempre, a antagonista da heroína.

É assim que os trajes das moças vão de acordo com as convenções relacionadas à inocência. Fazendas finas, sedas, brocados c rendas predominam neste universo, favorecendo a criação de um mundo onírico, harmonioso e puro. Enquanto as mulheres são descritas a partir dos seus trajes, os homcns são apresentados de forma mais direta através da descrição dos seus aspectos físicos, tais como a compleição viril, os ombros largos, um tómax bem delineado, simbolizando força física c poder. 


\subsection{Cenários}

O amor pode acontecer tanto nos desertos árabes, na distante Rússia dos czares como nas frias mansões ancestrais francesas e inglesas. Apesar de não haver referências a relações sexuais em seus livros $^{12}$, o relacionamento homem-mulher é explosivo em termos de conjunção emocional. A primeira reação das personagens ao homem amado é sempre traumática, agressiva, permeada de emoções incontroláveis. A estrutura amor-ódio está, pois, presente na trama de forma clara. Mas, essa explosão emocional entre homens e mulheres, quase sempre redunda, na subordinação da mulher ao macho dominador.

A descrição de cenários luxuosos é recorrente, o lar suntuoso e aconchegante provia a jovem mulher de suas necessidades. 'Alguns belos móveis antigos, tapegarias de tons delicados, num tapete claro circundado de guirlandas de rosas pálidas, davam-lbe um ar de elegância discreta.' (Foi o Destino, 1955: 56). O ambiente predileto são os castelos, símbolo de uma classe social superior. Nele, os cenários descritos para o habitat feminino são os espaços domésticos e mesmo estes são selecionados. Às heroínas, os jardins, as salas de visita, os vestibulos e os corredores, e, algumas vezes, os quartos. Neles, bordava-se, pintava-se, fazia-se tricô, tocava-se instrumentos musicais, cantava-se. Raramente as áreas de serviço eram descritas, este era o espaço destinado aos serviçais. No entanto, as mulheres supervisionavam a casa e os serviços domésti$\cos$ (Cunha, 1999). Aos homens, no espaço doméstico, as salas de visita e as bibliotecas. Na esfera pública, supervisionavam as terras cultivadas. Os bosques apareciam quando em passeios com as protagonistas.

Apesar das heroínas não se entregarem aos prazeres mundanos como as vilãs, algumas diversões fora do lar lhes eram outorgadas. Nos bailes, as heroínas, ainda solteiras, recebiam os olhares apaixonados de seus futuros pretendentes, encantando-os com suas habilidades para a dança, para a conversação, para o canto, ou o piano, instrumento mais nobre nos salões da época (Del Priori, 2006). A leitura, quando descrita, era vinculada a uma literatura religiosa, quando se distanciava um pouco desta temática, partiam para os clássicos, indicados por seus pais, tutores ou maridos.

Porém, qualquer obra que pertença a esta coleção retrata sempre a luta feminina por conservar sua honra intacta num mundo

12 Esta orientação não foi seguida por Elinor Glyn que descrevia, em suas obras, cenas de amor consideradas tórridas para a época. 
cheio de armadilhas. Por jsso, suas heroinas vivem em um universo no qual é proibido sair de casa sozinha, conversar com estranhos, ficar a sós com homens e manifestar desejos sexuais. O sexo é camuflado, sabe-se que ele é parte constituinte da vida conjugal, o gerador de filhos, mas esse fato natural da espécie não se comenta em público (Del Priori, 2006). Neste cenário, entre os anos 40 e 60, os romances de M. Delly serviam de válvulas de escape para uma vida cheia de formalidades, na qual a maior parte dos desejos de independència feminina era sufocado pela estrutura social. Restava como alternativa às mulheres desse periodo somente a busca por um amor que as libertasse de uma estrutura repressora, ainda que esta liberdade fosse encontrada nos laços do matrimônio, o que significava a continuidade do processo repressivo (Radway, 1997).

\subsection{Enredo}

Nos romances da Biblioteca das Mogas, o enredo e as personagens analisadas devem ser relacionados com as micro e macro estruturas que caracterizam este gênero. Entre essas estruturas está o excesso de descrição de lugares e ambientações, o uso de adjetivações hiperbólicas, a revelaçào freqüente dos sentimentos e emoções das heroínas e o recorrente drama da donzela em perigo salva pelo herói viril. Esta estrutura revela, assim, a lógica temporal e social das ações que exibe. Daí porque esses romances, em geral, seguiam as orientaçoes ideológicas da sociedade leitora de seu tempo- aí está a carga de realidade e credibilidade dos fatos representados e das personagens criadas para a sua sociedade leitora. Neste contexto, o enredo dessas romances seguia a velha fórmula folhetinesca, mas, agora com o inevitável final feliz.

Assim, nestes livros, no desenvolvimento da narrativa, a adjetivação é um recurso de linguagem presente e abundante. Ela revela a necessidade de supervalorização das aventuras vividas pelas heroinas. A narrativa constrói uma história de amor que se inicia a partir da luta moral da heróna em resistir às tentaçòes do mundo, engendradas pelos vilòes. Essa fortaleza de caráter, reconhecida pelos heróis, desiludidos por mulheres interesseiras e vis, é o que sustenta a trama. Aqui, amor e admiração são sinônimos. Ultrapassado o conflito inicial, identidades trocadas, erros de comunicação, suspeitas de traições, cinismos morais, os dois corações finalmente entram em harmonia e podem ter a recompensa do final feliz. 


\section{Julia, Sabrina e Bianca: as felizes cinderelas modernas}

\subsection{Capas e títulos}

Os romances sentimentais dos anos 80 também apresentam capas chamativas. Em geral, destacam a figura de um homem e de uma mulher em interação, de frente um para o outro, com os rostos próximos, numa sugestão de beijo. Ao fundo, cenários paradisíacos, com o mar e o céu azul em destaque, circunscritos por uma figura geométrica ovalada, imitando, a moldura das fotografias da época.

Os títulos, semelhantes aos de M. Delly, são hiperbólicos. Mas, aqui, as referências à natureza, não aparecem mais com tanta frequiência. Em geral, temos substantivos como "amor", "paixão", "pecado", "inocência"; "lágrimas", "tormentas" que se referem a estados emocionais que moldam os seres apaixonados. Alguns títulos de grande sucesso: $U m$ bomem sem Compaixão, Prisão Dourada, Beijos ao Luar, Esposa Amante, Inocência e Pecado, Interhídio de Amor, Gaiola Dourada, Sorrisos e Lágrimas, Tormentas de Amor, Palauras de Amor, Paixão Ardente, Frenesi de Paixão.

\subsection{Cenários e personagens}

Nos "Romance do Corąãa", dos anos 80, assim como em M. Delly, o cenário é descrito em minúcias e com palavras grandiloqüentes a fim de enfatizar a importância dos personagens e das situações vividas.

Andou até amurada por entre várias mesinhas coloridas com guarda-sóis listrados; uma churrasqueira dominava toda uma parede com seus tijolinhos vermelhos e uma enorme varanda assoalhada de madeira, suspensa sobre pilares de concreto, parecia flutuar sobre o mar. (Estátua de Mulher, 1985: 58)

A cena romântica que antes ocorria nos castelos medievais foi transferida para cenários idílicos de países distantes. Da gelada e ao mesmo tempo florida Inglaterra, passamos para os vinhedos franceses, dos vinhedos chegamos até as ruas repletas de obras de arte italianas, das ruas históricas, voamos para as ensolaradas ilhas gregas. As heroínas dos "Romances do Corafão" passeiam ou trabalham em lugares paradisíacos nos quais 'o sol ardente em um caleidoscópio de cores parece se fundir com a linba do borizonte'. 
Como cm M. Delly, é nesse cenário descrito de mancira minuciosa que a vida cotidiana se desenrola. A adjetivação ocorte de mancira abundante, mostrando, tal qual sua antecessora, o luxo c a riqueza. Se em M. Delly, há um detalhamento em relação aos corredores, às salas de visita, às escadarias, aqui, cntram $\mathrm{cm}$ ccna os quartos, minuciosamente descritos. O ccnário apresentado ć scmpre rico, peças raras compõem a decoração que obedecc a uma verdadcira ostentação de poder. $A$ descrição do cenário sc hibridiza com a descrição das personagens que são apresentadas também em sua relação com a natureza. Os olhos do herói da história têm a 'cor do mar em lempestade', os cabelos da heroína britham como 'umil moile estrelada'. Os ambientes externos são sempre fenomenais, claros e luminosos. As cadciras, paredes, sofás c objetos que farcm partc da casa-rua são caracterizados pelo seu valor artístico, histórico e financeiro.

Da alocação dos cenátios percebc-se que os romances da década de 80 privilegiam os ambientes públicos. Os lugares de trabaiho aparccem afinal. Em geral, são grandes firmas c hospitais. Os cscritórjos se tornam espaço de destaque, onde o herói comanda scus inúmcros subordinados. São normalmente descritos com pompa. O luxo ć a tônica que se percebe através das peças raras de paiscs longinquos adquiridas $\mathrm{cm}$ viagens. Quando as mulheres aparecem no ambiente de trabalho, estc é represcntado de forma simples, fazendo um contraste com o poder c a riqueza que hão de usufruir quando casarcm.

No que conccrne à descrição das particularidades de carátcr dos heróis e das heroínas, cabe ressaltar que apesar de apresentarcm difcrenças em relação aos valores postos como características de cada gênero, obedcce à mesma lógica narrativa dc $\mathrm{M}$. Delly: As heroínas da década de 80 são ativas, cxercem funções no mundo do trabatho, são intcligentes c cxpressam opiniões dentro dos limitcs sociais impostos ao feminino. Mas, continuam, a screm virgens, com o diferencial de terem, cm muitos casos, namorado com outros homens, trocando nestes intcrlúdios carícias "inocentes". Porćm, continuam assim como suas avós, a descjarem ardentemente o amor arrebatador, único c cterno. São lindas sem artifícios - tal como as heroínas de M. Delly - ainda que não sofisticadas. A sofisticação ć característica da vilã que a usa para scus fins nefastos. São simples. Não procuram aos prazcres mundanos e quando o fazcm ć apenas por má orientação, que sob o comando masculino deverá scr corrigida. 


\subsection{Enredo}

Apesar dessas pequenas diferenciações, como nos lembra Radway (1997), este tipo de literatura obedece a uma estrutura central, que sofre pequenas modificações ao longo das décadas. Em ambas as coleções, a regra do final feliz permanece.

Fomos feitos um para o outro, querida e o destino aproveitou-se dos correios para fazer minha carta chegar a suas mãos. Unidos pelo destino? Gostei - Dayse comentou, rindo, antes que Steve a fizesse calar com um beijo ardente (Onde está o amor?, 1985:123)

As grandes diferenças fundamentais entre as duas coleções são: a) o aparecimento, nos romances dos anos 80 , de muitas cenas em que há relações sexuais explicitamente descritas; b) o fato dos heróis e das heroínas exercerem profissões liberais e c) $O$ fato das heroínas não terem experiência sexual, mas, a desejarem fervorosamente como um sinal da chegada do verdadeiro amor.

No que concerne às profissões liberais, elas aparecerem tanto para os homens quanto para as mulheres. Essas mudanças abarcaram as transformações ocorridas neste intervalo de tempo entre as funções desempenhadas por homens e mulheres na sociedade (Giddens, 1993). No entanto, há restrições a essas mudanças. Na década de 80 , as heroínas, ainda que atuem na esfera pública, são descritas apenas como executoras de carreiras tipicamente femininas como a enfermagem, secretariado, vendas e o magistério de ensino fundamental, sempre em papéis de subordinação.

Em geral, quando trabalham em hospitais, estão subordinadas a um médico de sucesso - que será o eleito do seu coração. Quando em empresas ou lojas de departamento, elas subordinam-se ao dono da empresa, em regra, também àquele que será o seu grande amor. Os homens dos anos 80, nestes romances, exercem, assim, papéis de comando. São médicos de sucesso ou empresários multi-milionários, freqüentadores do high-society. Em alguns casos, são arqueólogos, fazendeiros ou engenheiros também de renome. Observamos que apenas a função social de homens e mulheres se transformou nos romances dos anos 80 , pois, o papel social desempenhado por ambos permanece o mesmo. De aristocrata a empresário, o salto 
em termos de poder social não é tão grande assim. A mudança mais significativa está no fato da mulher ascender à esfeta pública ainda que se conserve sob o domínio masculino.

Se a mulher trabalha fora do lar, nem ela própria nem a sociedade consideram esse trabalho tão importante para a sua definição social como o seu papel na estrutura familiar. O cuidado com os filhos é visto como sendo de sua responsabilidade, e sua situação de vida não é outra senão a de cuidadora do marido, dos filhos e do lar. Essas características estão presentes ainda na estrutura argumentativa dos romances sentimentais modernos tal como o foram $\mathrm{cm}$ seus predecessores. Assim, a submissão feminina é a tônica nesses enredos, seja em meados ou $\mathrm{em}$ fins do século passado. Em ambos os romances, a realização feminina depende do encontro de um parceiro masculino, que restringe sua participação no mundo público e a exige no mundo privado.

Como diferencial dos enredos do final do século, as personagens masculinas trabalham exercendo uma profissão liberal, mas continuam ricos e poderosos, são homens de destaque na sociedade. Ao caráter viril, acrescenta-se a sensualidade representada por uma renomada experiência sexual que usam para dar prazer às suas amadas, escravizando-as pelos prazeres sexuais. Uma característica que varia de romance a romance é a origem do herói. Se em M. Delly, ele é sempre nobre, nos romances dos anos 80 , tanto podem ser ricos de nascimento como podem ter vindo de condições adversas, tendo conquistado dinheiro e poder por seus próprios meios.

Un elemento estrutural diferenciado entre os romances dos anos 40 e o dos anos 80 , é o jogo da sensualidade entre o homem e a mulher. Nos anos 80 , a relação da mulher com o corpo vai se modificando. $O$ corpo começa a ser explorado e exibido pelo mundo midiático. As mulheres agora esbanjam sensualidade (Heilborn, 1999). Este processo envolve roupas decotadas, que desenham suas formas, num mostrar/ocultar instigante, além de insinuar outros atributos físicos ainda proibidos à exposição no espaço público. Nos romances, embora usem de todos esses artificios para acelerar o processo de sedução debitam esta façanha ao homem.

É nesse contexto dos anos 80 que Sabrina, Júlia e Bianca se tornam romances bem mais "apimentados" nos quais o corpo da muIher é descrito com riqueza de detalhes, não existindo mais a preocupação anterior em escondê-lo. Até mesmo o ato sexual é apresentado 
de forma explícita. Nestas descrições, a mulher revela um desejo sexual semelhante ao do homem. Suas heroínas, apesar de não tomarem a iniciativa no ato sexual, participam ativamente deste.

Lentamente ela fez o corpo deslizar sobre o dele, aproximando os lábios do sexo ereto e vibrante. Novamente moveu todo o corpo até alcançar o sexo dele e abriu-se toda para recebê-lo. Começaram a moverem juntos, numa só dança de fogo e paixão...gemeu até o gozo forte, doce, doloroso. (Estátua de Mulher, 1985:127-128)

Os olhos dela, deslumbrados, andaram lentamente pelo corpo dele. Eva, ao ver Adão pela primeira vez, deve ter tido nos olhos o mesmo brilho, na pele o mesmo arrepio, no coração o mesmo desejo (Estátua de Mulher, 1985:86).

Mas, se as heroínas dos anos 80 ainda esperam pelo homem ideal, a virgindade embora existente até a chegada deste homem, deve desaparecer com ele, antes ou depois do casamento, dependendo de cada romance. No entanto, se acontecer antes, o casamento, com ou sem o fruto do amor proibido, é o fim último da relação. Nessa situação, a mulher só se entrega a uma relação sexual porque se crê apaixonada.

No geral, cremos que os romances dos anos 80, Sabrina, Júlia e Bianca apresentam a mesma estrutura básica de M. Delly. Do mundo de duques e duquesas, passa-se para o universo de empresários e socialities. Tanto nos romances dos anos 40 e 60 como dos anos 80 , o espaço público é considerado masculino e o espaço privado feminino. O espaço público é o de produção, o mundo dos negócios, do financeiro, da notoriedade, já o espaço privado é o da reprodução, associado ao lar, aos cuidados com a família, à supervisão da casa, à criação dos filhos. Nesses romances, apesar das mulheres terem conquistado um certo trânsito no espaço público, esse não deixa de estar associado ao homem. Ainda que seja possível observar uma separação das esferas de atuação de homens e mulheres, as identidades machistas fixadas sobre gênero ainda são muito fortes, apesar do caráter fragmentado do conceito moderno de identidade (Stoller, 1993).

O enredo dos romances dos anos 80 passa por uma questão de identidade feminina perdida e restaurada. No início da narrativa, há uma desestruturação da vida familiar da heroína por morte, falência, doença grave na família, levando-a ao enfrentamento de dificulda- 
des. Neste momento, ela encontra o herói que lhe oferece sua ajuda em troca de determinados favores. A hcroína refuta cmocionalmente ao macho dominador. A cstória é marcada por um descjo sexual recíproco incontrolável, mas, ao acreditar que tal desejo não cstá emoldurado pelo amor, a heroína se afasta emocionalmente do herói até que ele se rcvele apaixonado. Neste momento, o casal se une e a identidade da heroína é restaurada. Mas, agora ela não existe por si só, a heroína só reconhece a si própria na relação que estabelece com o marido-amante.

\section{Romances sentimentais: o império do amor, do casamento e do final feliz}

As mulheres dos romances dos anos 80 , semelhantes às de M. Delly, esperam como fim último de sua existência social o casamento. $A$ descoberta do amor entre as personagens prepara a leitora para o recorrente final feliz. Enquanto a mulher não encontra o seu par ideal, ela é ainda um ser incompleto. Tudo que foge a este formato tende à infelicidade, ao fracasso e ao desprezo social. O típico exemplo é o da mulher que não encontrou o seu grande amor e não se realizou pelo casamento. Sem o casamento a mulher da década de 40 e também da década de 80 , não se reconhece como um ser autônomo e responsável por uma vida equilibrada e feliz.

Vale ressaltar que, por mais bem resolvida que se encontre na área profissional, isso não quer dizer que esteja feliz no campo sentimental, somente o homem amado é capaz de complementar sua vida, de torná-la plena. Profissionalmente realizada, ela continua em busca de um grande amor. Assim, quando se casa, geralmente, abandona a profissão e passa a viver somente para o marido e filhos.

Nos "Romances do Coraçāo", no que concerne à representação masculina, o herói é sempre posto como estabilizado na vida, já tendo alcançado a plenitude da carreira profissional e ampla experiência no campo sexual, estando, no momento en que se passa a história, pronto a assumir o verdadeiro amor. Este será abençoado pelo encontro da amante-esposa- mãe. Geralmente, o herói é bem mais velho que a mocinha da história, dai a razão de sua ampla experiência e de seu papel de professor no exercício da sexualidade e de protetor no âmbito sentimental.

O amor, para as heroínas dos "Romances do Coração" é o amor à primeira vista. As protagonistas passam boa parte da sua vida 
se preparando para este momento que será vivido em plenitude. Esta preparação é necessária a fim de que ela possa identificar a sua chegada e, assim, lutar ${ }^{13}$ posteriormente por ele, ainda que, nos primeiros momentos da trama, ela possa, devido a intrigas ou ao choque da descoberta, não reconhecer no eleito de seu coração a sua alma gêmea. $\mathrm{O}$ amor entre os protagonistas, muitas vezes, se dá, por meio da chantagem do herói que tenta salvar a heroína da ruína financeira, forçando-a a um casamento aparentemente sem laços emocionais.

Em muitas situações, mesmo quando são caluniadas, elas assumem uma atitude passiva, ou seja, escolhem continuar a serem acusadas e humilhadas por algo que não cometeram a se impor perante seus acusadores e livrarem-se das acusações. Os heróis devem descobrir as intrigas por si próprios guiados pelas circunstâncias ou pelas poucas personagens secundárias que a trama comporta. É a consagração da máxima popular "a verdade sempre vem à tona", sendo assim, não há porque elas lutarem pela sua inocência, uma vez que, mais cedo ou mais tarde, a inocência será re-estabelecida pela justiça (Andrade, 2000).

Assim, elas amam intensamente. São capazes de adoecerem gravemente ou até morrerem por amor, quando não correspondidas. Entretanto, não são capazes de contrariar sua educação nem sua conduta moral em prol da manutenção deste amor. Nestes romances, quem passa por cima destas questões, será sempre a vilã da história, que ao contrário da heroína, tem um caráter ativo na trama (Andrade, 2003).

As heroínas jamais tomam a iniciativa do ato sexual. Esperam que seu companheiro venha, as tomem nos braços, que as realizem, que as completem num ato viril e salvador. Este caráter passivo das heroínas "modernas" encontra ainda sua matriz nos romances folhetins do século anterior. Cabe aos heróis folhetinescos desvendarem as intrigas e salvar as mocinhas injustiçadas das mãos de seus algozes. As heroínas, pelo menos até a década de 80 do século $\mathrm{XX}$, são representadas em atitudes submissas e conformadas na trama. O homem é, pois, representado pelo critério da ação e a mulher pelo ardor dos sentimentos.

Quando o amor é encontrado, ela deixa o trabalho anterior, podendo dedicar-se ao sonho de realização: o cuidado da casa e dos filhos. Ainda que continuem trabalhando, o exercício de uma profissão não é mais prioridade em sua vida. Assim, o amor, tanto nos livros

13 Usamos o verbo lutar embora não seja uma palavra das mais adequada a estas personagens, uma vez que notamos um forte caráter passivo $\mathrm{em}$ suas heroínas. $A$ luta, aqui, pode ser definida no plano simbólico das emoções. 


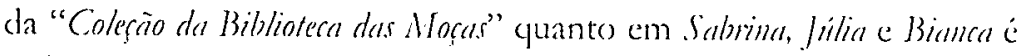
o fim último da vida de uma mulher, e sua recompensa é sempre a conquista do paraíso da felicidade a dois. Fista, cremos, é a estrutura final que garante aos romances sentimentais sua popularidade e sua passagem para o século XXl. 


\section{Bibliografia}

$\triangle N D R A D E$, Roberta Manuela Barros. O Fascinio de Sherazude: os usos sociais da telenovela. São Paulo: $A$ nablume, 2003.

ANDR ADE, Roberta Manuela Barros. O Fim do mmndo: imaginátio e teledramaturgia. São Paulo: Anablume, 2000.

BARTIN, Laurense. Análise de Contendo. Lisboa: Ediçōes 70, 1999.

BORELLI], Silvia Helana. Ação, suspense, emorăo: literatura e cultura de massa no Brasil. São Paulo: EDUC/ FAPESP, 1996.

CUNHA, Maria Teresa Santos. Armadillas da sedução: os romances de M. Delly. Belo Hotizonte: Autèntica, 1999.

CUNHA, Maria Teresa Santos. Mulberes e romances: uma intimidade radical. São Paulo, 2006. Disponivel em: trp://test.scielo.br/ scielo. Acesso em: 25 de maio de 2006.

DEL PRIORI, Mary. Histórias do cotidinno. São Paulo: Contexto, 2001.

DEL PRIORI, Mary. História do amor no Brasil. 2 ed. São Paulo: Contexto, 2006.

ECO, Umberto. Pós Escrito O Nome da rosn, Rio de Janeiro, Nova Fronteira, 1985.

EISLER, Riane Tennehaus. O Prazer sagrado: sexo, mito e politica do corpo. Rio de Janeiro: Rocco, 1997.

GIDDENS, Anthony. A Transformação da intimidade: sexualidade, amor e erotismo nas sociedades modernas. São Paulo: Editora Da Universidade Estadual Paulista, 1993.

HEII_BORN, Maria Luíza. Sexualidade: o olhar das Ciências Sociais. Rio e Janeiro: Jorge Zaaar, 1999.

MEYER, Marlyse. Folbetim. Rio de Janeiro: Companhia das Letras, 1996.

RADINY, Janice. Reading the romance: women, patriarchy and popular literature. London: Verso, 1987.

STOLJ_ER, Robert Walther. Masculinidade e fomimilidade: represenlasgòes do gênero. Proto Alegre: Artmedica, 1993.

ZUMTHOR, P. A Leetra e a noz, São Paulo, Companhia das Letras, 1993. 
!

$r$

is

$\because$
.
.1

$\therefore$

224 